\title{
"PROPERTY" RIGHTS OF THE SURVIVING HUSBAND OR WIFE UNDER THE FRENCH CIVIL CODE
}

\author{
LAYTON B. ReGister \\ Philadelphia Bar
}

It is likely that the Franco-American marriages solemnized during the war and the not inconsiderable number which may take place in the future of our new international intimacy will bring to the law practitioner an increasing number of problems involving the rights, privileges, etc., of these husbands and wives in the lands and chattels of the other. There will be legal interests in lands abroad to be administered. Already Americans possess considerable real estate in France, and we may look for their holdings to increase. On the owner's death its transmission will be governed by French law, while a French domicil will also cause French law to be applied to the devolution of an American decedent's personal property. I propose a brief survey of the French law governing the surviving husband's or wife's legal interest in the other's estate. I shall deal only with French internal law and not with the problems of conflict of laws.

Matrimonial Régimes. The "property" relations of husband and wife during marriage are governed in France by any one of several systems, defined and regulated by the civil code. ${ }^{1}$ These systems are called matrimonial régimes. They come into existence by a solemn, written contract prior to marriage or by an election made at the time of marriage, or, in the absence of any declared intent, the law presumes and imposes the system known as the community régime. As the purpose of the French antenuptial agreement is to regulate the rights of the parties as to their existing and future acquired property, during marriage and upon its dissolution, the problem of the survivor's rights will in no small way depend upon the régime adopted and the terms of the contract.

The subject of the matrimonial régime is too large to be treated here. Attention can only be directed to its relation to the problem of the surviving husband's or wife's rights; for, since it may determine the future disposition of all the property falling under its terms, it may withdraw such property from the operation of the laws of testacy or intestacy. One of these régimes, which comes into existence only by contract or election, is that of the dot. ${ }^{2}$ There is no exact parallel in French law to the common-law estates of dower and curtesy. English dower and French dot are different. The dot is the property which the wife on marriage brings to the husband as a

\footnotetext{
${ }^{2}$ Civil Code, Title V, Du Contrat de mariage.
}

Arts. 1540-I58I. 
contribution toward the support of their married life. ${ }^{3}$ It is administered by the husband and must be restored to the wife or her heirs on the dissolution of the marriage. ${ }^{4}$ It may consist of any sort of property; it may come from the wife personally or it may be given to her by a relative or friend at the time of her marriage. As security for the restoration of her dot and of any other property rights which by antenuptial agreement or otherwise the wife acquires against her husband, she enjoys a lien upon his real estate called the "legal hypothec."' This lien is one of several which the law creates for the security of certain persons under particular conditions without any formal act on their part. ${ }^{6}$ In one way it operates not unlike the common-law dower in that it necessitates the joining by the wife in the husband's conveyance of his own lands in order to pass a title free of the lien. For the strengthening of her husband's credit, she may renounce or assign her lien whenever the right which the lien secures may be renounced or assigned. ${ }^{7}$ Otherwise, she is regarded as a secured creditor of her husband.8

Anomalous Succession or Legal Reversion. This is an exceptional privilege of inheritance enjoyed by an heir in the direct ascending line with respect to the specific object of a gift made by such an heir to his descendant. ${ }^{9}$ This privilege withdraws the particular object of gift from the estate of the deceased descendant donee and restores it to the donor. ${ }^{10}$ It thus diminishes the estate upon which the husband's or wife's testament or the intestate laws might otherwise operate and so affects the rights of each. By the anomalous succession ascendants inherit, to the exclusion of everyone else, such objects as they have given their descendants when these die without posterity and the specific objects are found belonging to the estate. If the objects have been alienated, the ascendant has an action to recover the price due the decedent by reason of the alienation, and any possessory action to recover the objects which the donee himself could have exercised at the time of his death. ${ }^{11}$

The rule is based upon a supposed intent of the donor. The ascendant is presumed to have desired to benefit his child or his grandchild exclusively and it is therefore but carrying out such parent's design to return the specific thing whenever the donor

\footnotetext{
${ }^{3}$ Art. 1540. "Art. 1564.

'Art. 2I2I; 2 Baudry-Lacantinerie, Précis de Droit Civil (Ioth ed. Ig08) sec. 1517; 3 ibid., sec. 966.

-Art. 2rar.

'Law of March 23, I855, sec. 9, amended by Law of February 13, I889.

8 But not preferred over a creditor holding a "hypothec" recorded prior to her marriage. Art. 1572 .

'Art. 747; 3 Baudry-Lacantinerie, op. cit., sec. 516; Berton, L'art de faire soi-même son testament (ro ed.) $\mathrm{x} 26$, note $\mathrm{I}$.

${ }^{10}$ André, Traité pratique et formulaire des testaments (3d ed. rgro) rog.

"Art. 747.
} 
survives the donee and his children. ${ }^{12}$ Such a gift must not, of course, be confused with a donatio mortis causa (invalid under French law) since it is not given in prospect of the donor's death. It returns to the donor, as in the gift mortis causa, because the motive of the gift ceases. But in place of its returning because the donor survives an anticipated death, it returns because of the death of the donee, who alone was intended to enjoy it.

The conditions of operation of the anomalous succession are (I) the predecease of the donee leaving no descendants and (2) his possession of the specific thing at death..$^{13}$ Unless these conditions coexist the property is treated as part of the succession and the surviving spouse has the same interest in it as in other property of the estate. The donee has the power to sell or give the property away or to will it. This power would seem to conflict with the condition that if the object is found among the donee's property at death the anomalous succession passes it to the donor-heir. The privilege and power to "will" the thing is supported on the theory that on the testator's death it instantly passes in contemplation of law to the legatee and is therefore not in his possession. This leaves but one narrow set of facts when the donor-heir's exceptional privilege of inheritance works a disadvantage to the surviving husband or wife, that is, when the donee dies intestate without descendants and the object itself is found in his possession. He is then regarded as never having owned the property.

Contractual Reversion. ${ }^{14}$ The contractual form of the legal reversion has a more important effect in diminishing the property to which a surviving husband or wife may lay any claim. Any donor is permitted to stipulate in his contract of gift that the object shall be restored if he survives the donee or the donee and his descendants. ${ }^{15}$ Such a stipulation annuls any alienation of the property by the donee and, with certain exceptions, restores it to the donor upon the happening of the condition, free of all liens. ${ }^{16}$ The contractual reversion comes into being only by express agreement and is not limited merely to heirs in the direct ascending line. In the legal reversion the object has to be found in the deceased's possession; he has a privilege and power of disposal inter vivos or by will. Under the contractual form the donee has no power over it at all until by the occurrence of the event named in the gift it vests absolutely in the donee. There are three events that may be stipulated in the gift as a reason for the reversion: predecease of the donee alone, and predecease of the donee and all his descendants. A third, not mentioned in the code, is recognized as lawful though not often encountered-the predecease of the

123 Baudry-Lacantinerie, op. cit., sec. 517 .

${ }^{13}$ 1bid., sec. 526; Art. 747.

${ }^{14}$ Arts. 95I, 952; 3 Baudry-Lacantinerie, op. cit., sec. 960-970.

${ }^{15}$ Art. 951. 


\section{YALE LAW JOURNAL}

donee without children. In the last case if the donee's child survives him the gift "vests" at once absolutely. ${ }^{17}$

The contractual reversion restores the gift to its donor free of liens. An exception is made in favor of the wife's lien upon her husband's lands, which has already been described. The wife's lien in general attaches to all the husband's lands to secure his obligations to his wife. But the contractual reversion exempts the gift from her lien except insofar as it secures the restoration of her dot and the benefits to which she may be entitled under her antenuptial contract. That lien continues a charge on the land subject to reversion, after its restoration to the donor. But if the other property of the husband is sufficient to repay the dot and meet all the obligations of the antenuptial agreement, the land is released from the lien. Again, for the lien to survive, the land which was the object of the benefaction must have been given by the same marriage agreement that created the wife's lien.18 That is, because the donor who is himself a party to a marriage agreement is presumed to subject his gift to the normal consequences of such an agreement even though he stipulates for its restoration. Nothing, however, prevents the donor expressly stipulating that his gift shall be free from his wife's lien under all circumstances.

Intestacy. The word "heir" in its broad, untechnical sense means one whom the law calls to succeed to the property of a deceased person. But technically French law divides successors into two classes, regular and irregular. Only regular successors are referred to as heirs; those called to succeed by any other title are termed irregular successors, and of these there are but two: the surviving husband or wife and the state. The law fixes the order of succession among legitimate and illegitimate heirs; in their absence the property passes to the surviving spouse, and, if none, escheats to the state. ${ }^{19}$ It regards with greatest favor the whole class of heirs, legitimate and illegitimate; in second line come the irregular successors, the surviving husband or wife and the state. Both husband and wife receive the same treatment. Both the legitimate and illegitimate brothers and sisters of a deceased natural child are placed in a position of favor over the natural child's surviving spouse. Where a natural child survives its parents and leaves no issue, the property which came to it from its

${ }^{17} 3$ Baudry-Lacantinerie, op. cit., sec. 960.

${ }^{13}$ Art. 952.

${ }^{10}$ Art. 723. Prior to the law of March 25, 1896, illegitimate successors were classed along with the surviving spouse and the state as irregular successors. The most important consequence of the distinction between regular and irregular successors is that the former have not only "title" but a privilege to take immediate possession of the deceased's property, while the irregular successor has first to win a judicial recognition and an order to take possession, known as "envoi en possession." Art 724; 3 Baudry-Lacantinerie, op. cit., secs. 458 ff.; I BaudryLacantinerie et Wahl, Traité de droit civil (1905) Des Successions secs. 138 ff. 
parents and is in its estate, passes to its legitimate brothers and sisters, while the balance passes to its natural brothers and sisters and their descendants. ${ }^{20}$ The natural children of the same mother or father are termed natural brothers and sisters. If the same mother or father also have legitimate children, these are deemed legitimate brothers and sisters of the natural children. After the property which has come from the deceased parents has been withdrawn or deducted from the illegitimate child's estate and has passed to its legitimate brothers and sisters the balance passes to the natural brothers and sisters in preference to the surviving spouse. ${ }^{21}$ It will be convenient at this point to present a table of the classes of successors in the order of their preference: ${ }^{22}$ ( $I$ ) Heirs, legitimate and natural: (a) Direct descendants to no matter what degree; ${ }^{23}$ (b) privileged ascendants and collaterals, i. e., father and mother, sister and brother ${ }^{24}(c)$ ordinary ascendants, i. e., grandparents to no matter what degree $;^{25}(d)$ ordinary collaterals, i. e., uncles and aunts; cousins to the I2th degree; ${ }^{28}(e)$ where it is a matter of the succession of a natural child who has survived its parents and dies without issue the legitimate and the natural brothers and sisters. ${ }^{2 \pi}$ (2) Irregular Successors: $(f)$ The surviving husband or wife ;8 $^{28}(g)$ the state. ${ }^{29}$

To realize the unfavorable position accorded the surviving husband or wife by French law, it must be understood that not until the law of March 9, I89I, was the code so amended as to provide a necessary allowance for maintenance to the survivor and a life estate where the survivor was deferred to some one of the six privileged classes of heirs. ${ }^{30}$ Even the pre-Napoleonic law was more generous. ${ }^{31}$ A wife's only protection has been, until the code was reformed, her antenuptial agreement, or marriage régime, or the husband's capacity, though limited, to provide for her by will.

In intestacy the surviving husband or wife is given absolute title to everything if none of the six privileged classes of heirs are living,

\footnotetext{
${ }^{2}$ The position of Art. 766 under the rubric "Des successions irregulières" has made it appear as though the legitimate and illegitimate brothers and sisters of a deceased illegitimate child were irregular successors. The best opinion seems to be otherwise since the law of March 25, 1896, which also altered this article. Baudry-Lacantinerie et Wahl, op. cit., sec. 492.

${ }^{21}$ The legal interest of the legitimate brothers and sisters of such a decedent is evidently modelled after the legal reversion or anomalous succession enjoyed by ascendants, already described. Art. 747.

"A clear presentation is found in Léon Parisot, Comment on partage une succession (I912) 49.

${ }^{23}$ Art. 745.

${ }^{25}$ Art. 746.

${ }^{2}$ Art. 766 .

$\Rightarrow$ Art. 768 .

${ }^{24}$ Arts. 748, 750, 751, 752.

${ }^{28}$ Arts. 753, 754.

${ }^{28}$ Art. 767 .

"I Baudry-Lacantinerie, op. cit., sec, 565 .
} 
and a life estate, of varying proportions according to circumstances, whenever the privileged classes step between the survivor and the absolute title. Ownership passes at once to the heirs, subject to a life interest in the surviving husband or wife. That the property may be freed from restraints that would affect its commercial value, the heirs are permitted, any time before final distribution, to transmute the life estate into a life annuity upon giving ample security. ${ }^{32}$ When the facts are such that the surviving husband or wife does not acquire an absolute title, and if there has been no decree of divorce or separation, a life estate is granted the survivor in the following proportions: (a) One-quarter, if the deceased leaves one or more children, issue of the marriage; $(b)$ a child's part equal to that of the least favored legitimate child, where the deceased leaves issue by a prior marriage. The surviving spouse is numbered as a child and receives a child's share. So calculated it may not exceed the part given to the least favored child-and never more than one-quarter. If there are six children, the life estate will be of one-seventh, and it may not be increased because one child has received special benefits; in no case may it exceed one-quarter. (c) One-half in all other cases, no matter what the number or class of the heirs.

The amount of the life estate is calculated by fictitiously adding to the corpus all gifts by the decedent to his heirs during life or by will, and all gifts to the decedent subject to the legal or contractual reversion. $^{33}$ It is actually enjoyed, however, only out of the decedent's property undisposed of at death. This means that a husband or wife may by gifts inter vivos or by will entirely cut off the surviving spouse. Only when the decedent dies wholly intestate is it certain that the life estate can be enjoyed by the surviving husband or wife without abatement; in case of partial intestacy it can only be enjoyed out of the property actually undisposed of; and in case of complete testacy the right and privilege disappear entirely. The privilege of election to take against the deceased's will is not recognized as in the common law.

Testacy. The French civil code privileges a testator to dispose of a part only of his estate by will if at the time of his death certain specially favored classes of heirs are living. This system is in contrast with the common law. The testator's estate is divided into two portions: (I) that which passes by law to certain designated heirs and which the testator may not diminish; and (2) that which passes by his own act or testament. The former is termed the reserve or the legal portion, the latter, the disposable portion. ${ }^{34}$ Whenever the favored heirs survive, it is as though the testator died intestate as to

${ }^{3}$ Art. 767; Baudry-Lacantinerie, op. cit., secs. 565 ff.; I Baudry-Lacantinerie et Wahl, op. cit., secs. $5 \mathrm{I} 4 \mathrm{ff}$.

3 Baudry-Lacantinerie, op. cit., secs. 568, 569 .

${ }^{24}$ Arts. 9r3-9I5; André, op. cit., secs. 194 ff. 
the reserved portion of his estate. If he has made a will giving that portion to persons other than reserve heirs his will is pro tanto inoperative. The reserve heirs enjoy an action against the legatees receiving from the undisposable portion, resulting in an abatement until the reserve is reesstablished. ${ }^{35}$ The reserve heirs are the testator's direct descendants and ascendants. No collateral heir, even a brother or sister, is a reserve heir; the surviving husband or wife is not deemed an heir at all, but an irregular successor, and a fortiori not a reserve heir. A testator may, therefore, cut off all save reserve heirs. The disposable portion is the same whether the testator is the husband or the wife. There is no distinction of sex.

The code first considers the portion which a testator may normally dispose of, that is to say what may be bestowed upon strangers or persons other than the surviving spouse. ${ }^{38}$ Unless an exception is made, at least as much of the estate may pass by will to the surviving spouse as the law permits to be willed to a stranger. The code later takes up the exceptional case of gifts between husband and wife and, while ameliorating their position generally, in some respects prejudices it. $^{37}$

The Portion Disposable to a Stranger. ${ }^{38}$ The law distinguishes several states of fact: $(a)$ the testator leaves no heirs in the direct line, descending or ascending. He is accorded full power of disposal over his entire estate since there are no reserve heirs. There is, therefore, no reserve, and, as the reserve and the disposable portion are complementary parts of the whole succession, the disposable portion comprehends the entirety. The husband or wife may become by will the recipient of the whole estate absolutely. (b) The testator leaves but one legitimate child: the disposable portion is one-half; the reserve of one-half goes by law to the child. (c) The testator leaves but two legitimate children: the disposable portion is one-third; the reserve of two-thirds passes by law to the two children. $(d)$ The testator leaves three or more legitimate children: the disposable portion is one-quarter; the reserve of three-quarters passes by law to the three or more children. (e) The testator leaves an illegitimate child. By the amendment of March 25, I896, to article 9r3, an illegitimate child is ranked as a reserve heir. A like proportion is maintained between the reserve of the legitimate and of the illegitimate child as is established between the portions which they respectively receive from an intestate parent. This throws us back upon article 758 , which was also rewritten by the law of March 25, 1896. It provides that an illegitimate child shall inherit one-half of what would have been its portion if legitimate. The reserve portion passing to the natural

\footnotetext{
ss Art. 920.

"Arts. 913-9rg.

${ }^{\mathrm{n}}$ Arts. Iogi-1100.

*Art. 913; I Baudry-Lacantinerie et Colin, Traité de droit civil; Des donations et des testaments (1905) secs. $698 \mathrm{ff}$.
} 
child is therefore one-half of what it would have been had the relationship been legitimate. As an example, let us suppose an estate of 30,000 francs and two children, one legitimate and one illegitimate. Had both children been legitimate their reserve would have been twothirds; each child would receive ro,00o francs and a like sum would be at the free disposal of the testator, subject, insofar as the wife or husband is concerned, to the limitations which I shall presently describe. By the amendment of March 25, 1896 , to article 758 , the illegitimate child's intestate portion is one-half of the legitimate child's. The same proportion is maintained between their reserves. The natural child therefore receives in our example one-half of 10,000 francs and the 5,000 francs cut from this portion augments the disposable portion. $(f)$ No heirs in the direct descending line survive but the testator leaves one or more in both ascending lines; the disposable portion may not exceed one-half the estate. ${ }^{30}(g)$ No heirs in the direct descending line survive but the testator leaves one or more in one direct ascending line only; the disposable portion may not exceed three-quarters of the estate. ${ }^{40}$ (h) No legitimate heirs in the direct descending line survive but the testator leaves one or more illegitimate children and heirs in one or both the direct ascending lines; the disposable portion may not exceed one-half if there is but one illegitimate child, one-third if but two, and one-quarter if there are three or more. Out of these reserves the ascendants have a prior right to a reserve in their favor of one-eighth of the entire estate.41

Gifts Between Husband and Wife. I have observed that where there are no reserve heirs the surviving spouse may receive the whole estate. $^{42}$ I have now to examine the particular rules which alter the testator's powers whenever reserve heirs and a surviving husband or wife find themselves in competition. ${ }^{3}$ As the reserve together with the disposable portion compose the entirety of the estate, any enlargement of the disposable portion is necessarily at the expense of the reserve and, being a derogation of the general rule, is strictly construed. There are three cases to visualize:

(I) The donor leaves no descendants in the direct line. A husband or wife may by antenuptial agreement or during marriage (by gift, testamentary or otherwise), in case no descendant survives, dispose absolutely in the other's favor of everything that the donor could dispose of in favor of a stranger. ${ }^{44}$

It will be remembered that article 914 provides that when there are

\footnotetext{
Art. 9I4.

4 Ar. 9 r5.

"Ibid.

Art. 916; 3 Baudry-Lacantinerie, op cit., sec. I24I; I Baudry-Lacantinerie et Colin, op. cit., sec. 68I.

Arts. $1094,1098$.

"Art. rog4; 3 Baudry-Lacantinerie, op. cit., sec. r243; 2 Baudry-Lacantinerie et Colin, op. cit., secs. 4032 ff.
} 
no descendants but heirs in both direct ascending lines the disposable portion is one-half and if heirs in but one ascending line, it is threequarters. A surviving husband or wife may, therefore, become the testamentary beneficiary by an absolute gift of one-half and threequarters of the estate respectively in these cases. As it stood before the amendment of February 14, I900, article I094 was more favorable to the survivor, permitting a testator to give a life estate in the whole of the reserve. But this made the reserve heirs' enjoyment in most cases illusory, as they were a generation older than the life tenant. They might never take possession and consequently a sale of the reversion was always at a sacrifice if the expectancy of life of the tenant were great. The life estate was therefore changed into an absolute estate of smaller proportions.

(2) The donor leaves descendants by the surviving spouse. He may give to the spouse either a fourth absolutely and a life estate in a fourth, or a life estate in one-half.45 The number of descendants is immaterial.

It may be asked what can the purpose have been to provide for a life estate in one-half, after empowering the donor to make an absolute gift of one-quarter plus a life interest in one-quarter. The latter is certainly greater in value than the life interest in the half and would, therefore, seem to include the lesser by implication. The explanation is that the testator might attempt to give a life estate having a commuted value equal to an absolute interest of a one-fourth. Such a life interest would be greater than a life estate in a fourth and it might thus be argued that a life estate in more than one-half was contemplated. Controversy was forestalled by the express declaration that if it were all given in the form of a life estate it could not exceed one-half the estate. $^{18}$ Thus the two alternatives differ both in quality and value; of the two the first is the more generous to the spouse.

In this respect the terms of article rog4 differ from the interpretation which courts and writers have placed upon the more general articles $913,914,915$ and 917 . In the latter group the legislator made the disposable portion an absolute estate and the question at once arose whether in the alternative it was permitted to give a life annuity purchasable for the amount of the disposable portion, the yearly income in such case of course being calculated as upon a principal in excess of the disposable portion. In determining what life estate is equivalent to an absolute estate, the tenant's expectancy of life must be taken into account, and as to this opinions may differ. Conflicts are-adroitly avoided by providing that the reserve heirs, the only ones whose interests can be impaired, shall decide whether the commuted value of the life estate is in excess of the reserve. If so, they may

“Art. 1094, 2d par.

* 3 Baudry-Lacantinerie, op. cit, sec. 1244. 
insist upon its reconversion into an absolute estate, for the reserve in no case may be impaired against the will of the reserve heirs. ${ }^{47}$ The rules which have been worked out by the courts governing the conversion of the absolute interest into an annuity under article 9I7 have no application to the situation of the surviving husband and wife under article I094, which does not permit the life estate to exceed one-half the principal. ${ }^{48}$

(3) The donor leaves children by a former marriage. The second spouse may not receive more than the portion of the least favored child, and in no case in excess of one-quarter of the estate. ${ }^{48}$ If, for example, the first marriage resulted in three children and the second in three, the surviving spouse may receive one-seventh; if there were but one or two children by the first marriage and none by the second, the surviving spouse could not receive more than one-quarter.

The last case presents an oddity. Where a testator leaves one child only, such testator has a privilege and a power of disposition over onehalf the estate, and in case of two children over one-third the estate. And yet when the child is by a prior union a gift to the surviving spouse may in no case exceed one-quarter. The same is true when the child is not by a former union. If there is but one child the reserve is one-half and the disposable portion one-half, while the surviving spouse may receive one-quarter absolutely and a life estate in onequarter only. There is a fraction which the decedent is not obliged to give to the children and is not permitted to give to the surviving spouse. It has been explained that the disadvantage which the surviving spouse here suffers as compared with the privilege of a total stranger is due to the angles from which the legislator looked at the problem in the two cases. In fixing the disposable portions generally, the aim was to leave a safe living for the privileged heirs; the legislator was indifferent as to what became of the residue. On the other hand, in fixing the disposable portion in favor of the spouse, the legislator aimed to provide means to maintain the accustomed standard of living for but one person; the number of the children, therefore, did not influence the result.

So it is true that in one set of circumstances a charitable institution or a friend, for example, of the testator is privileged by law to receive more than a surviving husband or wife. It may also be queried why the law should make the surviving spouse's situation least favorable as compared to the stranger precisely in the cases where, there being but one or two children, the disposable portion is largest. Of course, the disadvantage is only relative, because, as has been shown, the spouse's privilege to receive by will is unchanging no

\footnotetext{
"Ibid., sec. 8ig; Art. 917.

${ }^{48}$ Cassation, June 30 , I885, reported in (1885) Sirey, I, 352.

- Art. rog8; 3 Baudry-Lacantinerie, op. cit., secs. I248, 1256; 2 Baudry-Lacantinerie et Colin, op. cit., secs. $470 \mathrm{I}$; André, op. cit., secs. I3o ff.
} 
matter how many children there are, while the stranger's privileges vary with the family situation. Again, and vice versa, the more children there are to provide for the more favorable the surviving spouse's position is made as compared to that of the stranger legatee, inasmuch as while the latter's disposable portion is cut down the portion which the survivor may receive remains constant.

The Surviving Husband's or Wife's Right to an Allowance for Maintenance. The property of the husband or wife, in case of the poverty of the survivor, is chargeable with an allowance for maintenance. Claim must be presented during the year following the death of the husband or wife, or before distribution of the estate is concluded. The allowance is taken from the decedent's property, but supported by all the heirs; if the heirs' portions are insufficient, the legacies are charged proportionately. ${ }^{50}$ The allowance is a provision against the destitution and misery of the surviving spouse, who has been cut off by the testator or whose life estate under the intestate law may prove inadequate. It is clearly based upon public policy and may not be surrendered by agreement. The allowance is treated as a right or a claim against the estate which has passed by law directly and instantly to the heirs or legatees. It is not an inheritance and it is not an unliquidated reserve. No "title" or possession passes to the surviving spouse; rather is the allowance looked upon as a prolongation after death of the obligation of maintenance imposed upon the spouse during life. The rights of creditors are preferred. Divorce terminates the right but not judicial separation, because in the latter case the obligation of maintenance endures during life after the separation.

In considering the amount of the fortune of the decedent to be charged it is solely the "property" of the decedent which passes to the heirs and legatees that is examined. The state of their prior personal fortune does not weigh. Nevertheless the surviving wife, as an example, may find herself in a position of competition with the children of the deceased husband. The estate may not be ample enough to meet the needs of all. While no provision of the code has created a hierarchy of persons who owe an allowance for maintenance to those in need, it must be understood that the surviving spouse's allowance is only one of several such obligations created by law and the rules governing allowances in general are for the most part applicable to the surviving husband's or wife's. Decisions and text writers agree that the obligation rests primarily upon: ( $I$ ) husband or wife; (2) blood relations; and (3) relations by marriage. Consequently the surviving spouse who finds the estate too small to support all who are dependent upon it may turn to relations.

${ }^{50}$ Art. 205 as amended by the law of March 9, 189r; I Baudry-Lacantinerie, op. cit., secs. 504 to 508 . 